\title{
IV. ODNOWIENIE DOKTORATU PROFESORA JÓZEFA MÉLÈZE-MODRZEJEWSKIEGO
}

\author{
JAKUB URBANIK (Warszawa)
}

\section{Odnowienie doktoratu Profesora}

W dniu 6 czerwca 2011 roku licznie zgromadzeni w Sali Senatu Uniwersytetu Warszawskiego goście, byli świadkami uroczystego odnowienia doktoratu Profesora Józefa Mélèze-Modrzejewskiego. Obrona pracy doktorskiej Jubilata, będącej podstawą odnowienia stopnia doktorskiego, odbyła się przed ponad półwieczem na Wydziale Historycznym UW. Temat stanowi jednak ważkie zagadnienia prawne: problem małżeństw pisanych i niepisanych w prawie grecko-rzymskiego Egiptu; jej promotorem był jeden z ojców-założycieli papirologii prawniczej - Rafał Taubenschlag.

Nic zatem dziwnego, że wniosek historyków poparli także warszawscy prawnicy, a za prezydialnym stołem zasiedli ramię w ramię prof. Elżbieta Zybert, spectabilis decana Wydziału Historycznego, oraz prof. Krzysztof Rączka, dziekan Wydziału Prawa i Administracji Uniwersytetu Warszawskiego. Józef Modrzejewski to bowiem - na równi - historyk praw antycznych całej oikumenê i historyk starożytności, z domieszką judaisty i biblisty oraz znawcy antycznych społeczeństw. Odnowiony doktorat promował prof. Włodzimierz Lengauer, recenzowali papirolog Roger Bagnall (Uniwersytet Nowojorski), jus-grecystka Eva Cantarella (Uniwersytet Mediolański) i papirolog prawniczy Hans-Albrecht Rupprecht (Uniwersytet Marburski). W swej laudacji promotor podnosił wszechstronność zainteresowań Jubilata, jego najwyższej próby prace naukowe, wreszcie związki ze środowiskiem warszawskich starożytników. Mélèze-Modrzejewski to w jego oczach ,żyjący klasyk”, godny kontynuator „tradycji humanizmu europejskiego”, stojący na równi z „Guillaume Budé, Friedrichem Carlem von Savigny czy Theodorem Mommsenem”. Promotor konkludował, że „dzieło Józefa Mélèze-Modrzejewskiego ... to dowód, że można być specjalistą i zarazem prawdziwym humanistą, erudytą w dawnym, najlepszym stylu, ogarniającym całość ogromnej dzie- 
dziny wiedzy i kultury, w której mieści się jego dyscyplina”, a „Uniwersytet Warszawski może być dumny ze swego doktora".

Odnowiony warszawski dyplom dołącza się do dwóch francuskich stopni doktora nauk prawnych i nauk humanistycznych (w roku 1970, Uniwersytet Paryż II - Panthéon: Loi et coutume dans l'Égypte grecque et romaine. Recherches sur les facteurs de formation du droit privé en Égypte aux temps des Lagides et sous la domination romaine, oraz sześć lat później, Uniwersytet Paryż I - Sorbona: Droit et société dans l'Égypte grecque et romaine. Recherches de papyrologie et d'histoire ancienn), doktoratu honoris causa Uniwersytetu Ateńskiego oraz innych licznych wyróżnień naukowych i wspólnotowych. Jest Józef Mélèze-Modrzejewski członkiem korespondentem heidelberskiej Akademie der Wissenschaften, Akademii Ateńskiej, członkiem zagranicznym Polskiej Akademii Umiejętności i Polskiej Akademii Nauk oraz członkiem rzeczywistym Europejskiej Akademii Nauk, Literatury i Sztuk, kawalerem Orderu Zasługi RP. Jego poczytne książki naukowe otrzymały wiele nagród: ostatnio Prix François Millepierres Akademii Francuskiej i Prix Victor Delbos de l'Académie des sciences morales et politiques. Ponadto, Modrzejewski to wydawca „Revue historique de droit français et étranger”, zasiada też w radach naukowych najistotniejszych periodyków naszej dyscypliny - obok „Czasopisma Prawno-Historycznego" - wspiera swą wiedzą „The Journal of Juristic Papyrology” (Warszawa), ,Iura. Rivista internazionale di diritto romano e antico” (Neapol), ,Revue internationale des droits de l'Antiquité”, a także Cahiers du Centre Glotz („Revue d'histoire ancienne”) (Paryż) i „Dike. Rivista di storia del diritto greco ed ellenistico" (Medolian).

Odnowienie doktoratu podkreśla również i ten ważki fakt, że mimo, iż od roku 1958 Uczony mieszka poza krajem - przede wszystkim we Francji, ale też, jako profesor wizytujący, w Marburgu, Princeton, Tel Awiwie, Londynie i Brukseli, to nigdy nie zarzucił intelektualnych i osobistych kontaktów z Polską, a przede wszystkim z Uniwersytetem Warszawskim. Tu właśnie ma rzeszę oddanych przyjaciół, kolegów i osób, dla których zaszczytem jest zaliczenie w poczet Jego licznych międzynarodowych uczniów: wypromowanych doktorów, adresatów recenzji doktorskich, habilitacyjnych i profesorskich.

Wiele można by pisać o zainteresowaniach naukowych Jubilata, niech mi wolno będzie jedynie delikatnie je naszkicować, zresztą skupiają się one - jak w soczewce - w dalej przytoczonym wykładzie doktorskim (por. s. 399). Modrzejewski to polihistor, jego dorobek zawiera zarówno prace niemalże klasycznie-romanistyczne, jak i ius-grecystyczne. Nieobce są mu również wątki prawa biblijnego i historii Narodu Wybranego: przez lata prowadził na Wolnym Uniwersytecie Brukselskim seminarium z historii Izraela, ostatnio spod jego pióra wyszło thumaczenie i komentarz Trzeciej Księgi Machabejskiej w pomnikowej Biblii Aleksandryjskiej. Od początku jednak naukowej drogi w centrum zainteresowania Modrzejewskiego leży prawo Egiptu grecko- 
rzymskiego we wszystkich jego aspektach: legislacja Ptolemeuszy, konflikt praw, rzymska organizacja podbitej prowincji, ale też - codzienne użycie prawa, pozornie błahe sprawy zwykłych ludzi, których podglądanie przez „okno kuchenne" pozwala rekonstruować praktykę prawną w życiu codziennym. Prace Modrzejewskiego - wolne od wszelkiego ahistoryzmu, anachronizmów oraz pewnego nadmiernego rygoryzmu, właściwego niestety typowym badaczom prawa, wpisują się w - obecnie najistotniejszy - nurt badań nad starożytnością: historię mentalności. Dzięki Niemu zacierają się sztucznie postawione bariery: „rzymskości”, „egipskości” czy „greckości”, „prawa państwowego (Reichsrecht)" i „prawa prowincjonalnego czy «ludowego» (Volksrecht)”, „historii” i ,historii prawa” wreszcie. Dostępność pisarstwa Modrzejewskiego jest nie do przecenienia: w każdym języku, w którym pisze, jego niezwykłej klarowności i pełne elegancji eseje skrzą się od błyskotliwych porównań i frapujących przykładów. Próbę kunsztu Jubilata znajdzie Czytelnik w jego wykładzie doktorskim ${ }^{1}$ oraz w wydanym z okazji warszawskiej uroczystości zbiorze, właściwie napisanych od nowa, tekstów układających się w prawdziwą syntezę porządku prawnego świata hellenistyczno-rzymskiego ${ }^{2}$. Nierzadko można posłyszeć, że to właśnie dzięki Niemu historycy rozumieją zawiłości prawa, a prawnicy nie zapominają o historycznym kontekście swoich rozważań.

Nie ma wątpliwości, że Józef Mélèze-Modrzejewski daje dobitny przykład prawdziwości stwierdzenia o amicitia papyrologorum, a od początku swej drogi naukowej podąża za rotą przysięgi doktorskiej: nie tylko wytrwale poszukuje prawdy, ale czyni ją dla wszystkich na tyle przystępną, iż światło pomyślności rodzaju ludzkiego rozbłyska jeszcze jaśniej.

\footnotetext{
${ }^{1}$ Przemówienie Jubilata zamieszczamy w niniejszym zeszycie poniżej.

${ }^{2}$ Joseph Mélèze-Modrzejewski, Droit et justice dans le monde grec et hellénistique (red. J. Urbanik), Warszawa 2011 („The Journal of Juristic Papyrology Supplements” X), XXII-565 pp.
} 
